\title{
Clear Cell Acanthoma
}

National Cancer Institute

\section{Source}

National Cancer Institute. Clear Cell Acanthoma. NCI Thesaurus. Code C97041.

An acanthoma characterized by the presence of psoriasiform epidermal acanthosis and basal cells with pale cytoplasm. 